Q2W than PBO attained ACR50, improvement in HAQ-DI $\geq 0.35$, MDA, DAS28$\mathrm{CRP}$, and DAPSA $\leq 14$. Improvement persisted on all measures through Week 52.

\begin{tabular}{|c|c|c|c|c|c|c|}
\hline & \multicolumn{3}{|c|}{$\begin{array}{c}\text { 1-TNFi Inadequate Responder } \\
n / \mathrm{N}(\%)\end{array}$} & \multicolumn{3}{|c|}{$\begin{array}{l}\text { 2-TNFi Inadequate Responder } \\
n / N(\%)\end{array}$} \\
\hline & PBO & Q4W & Q2W & PBO & Q4W & Q2W \\
\hline \multicolumn{7}{|l|}{ ACR50 } \\
\hline Week 24 & $\begin{array}{c}2 / 68 \\
(2.9 \%)\end{array}$ & $\begin{array}{c}24 / 71 \\
(33.8 \%)^{\star \star}\end{array}$ & $\begin{array}{c}19 / 65 \\
(29.2 \%)^{* *}\end{array}$ & $\begin{array}{c}3 / 41 \\
(7.3 \%)\end{array}$ & $\begin{array}{c}15 / 41 \\
(36.6 \%)^{*}\end{array}$ & $\begin{array}{c}16 / 46 \\
(34.8 \%)^{*}\end{array}$ \\
\hline Week 52 & - & $\begin{array}{c}29 / 71 \\
(40.8 \%)\end{array}$ & $\begin{array}{c}20 / 65 \\
(30.8 \%)\end{array}$ & - & $\begin{array}{c}18 / 41 \\
(43.9 \%)\end{array}$ & $\begin{array}{c}13 / 46 \\
(28.3 \%)\end{array}$ \\
\hline \multicolumn{7}{|c|}{$\begin{array}{l}\text { Improvement in HAQ- } \\
\mathrm{DI} \geq 0.35^{\mathrm{a}}\end{array}$} \\
\hline Week 24 & $\begin{array}{c}9 / 61 \\
(14.8 \%)\end{array}$ & $\begin{array}{c}28 / 61 \\
(45.9 \%)^{\star \star}\end{array}$ & $\begin{array}{c}19 / 58 \\
(32.8 \%)^{*}\end{array}$ & $\begin{array}{c}7 / 38 \\
(18.4 \%)\end{array}$ & $\begin{array}{c}16 / 36 \\
(44.4 \%)^{*}\end{array}$ & $\begin{array}{c}20 / 41 \\
(48.8 \%)^{*}\end{array}$ \\
\hline Week 52 & - & $\begin{array}{c}32 / 61 \\
(52.5 \%)\end{array}$ & $\begin{array}{c}18 / 58 \\
(31.0 \%)\end{array}$ & - & $\begin{array}{c}14 / 36 \\
(38.9 \%)\end{array}$ & $\begin{array}{c}13 / 41 \\
(31.7 \%)\end{array}$ \\
\hline \multicolumn{7}{|l|}{ MDA } \\
\hline Week 24 & $\begin{array}{c}3 / 68 \\
(4.4 \%)\end{array}$ & $\begin{array}{c}22 / 71 \\
(31.0 \%)^{\star *}\end{array}$ & $\begin{array}{c}14 / 65 \\
(21.5 \%)^{*}\end{array}$ & $\begin{array}{c}1 / 41 \\
(2.4 \%)\end{array}$ & $\begin{array}{c}8 / 41 \\
(19.5 \%)^{*}\end{array}$ & $\begin{array}{c}13 / 46 \\
(28.3 \%)^{\star \star}\end{array}$ \\
\hline Week 52 & - & $\begin{array}{c}26 / 71 \\
(36.6 \%)\end{array}$ & $\begin{array}{c}17 / 65 \\
(26.2 \%)\end{array}$ & - & $\begin{array}{c}11 / 41 \\
(26.8 \%)\end{array}$ & $\begin{array}{c}7 / 46 \\
(15.2 \%)\end{array}$ \\
\hline \multicolumn{7}{|c|}{ DAPSA $\leq 14$} \\
\hline Week 24 & $\begin{array}{c}11 / 68 \\
(16.2 \%)\end{array}$ & $\begin{array}{c}30 / 71 \\
(42.3 \%)^{\star *}\end{array}$ & $\begin{array}{c}24 / 65 \\
(36.9 \%)^{*}\end{array}$ & $\begin{array}{c}2 / 41 \\
(4.9 \%)\end{array}$ & $\begin{array}{c}14 / 41 \\
(34.1 \%)^{*}\end{array}$ & $\begin{array}{c}12 / 46 \\
(26.1 \%)^{*}\end{array}$ \\
\hline Week 52 & - & $\begin{array}{c}41 / 71 \\
(57.7 \%)\end{array}$ & $\begin{array}{c}26 / 65 \\
(40.0 \%)\end{array}$ & - & $\begin{array}{c}18 / 41 \\
(43.9 \%)\end{array}$ & $\begin{array}{c}14 / 46 \\
(30.4 \%)\end{array}$ \\
\hline \multicolumn{7}{|c|}{ DAS28-CRP Good } \\
\hline Week 24 & $\begin{array}{c}7 / 68 \\
(10.3 \%)\end{array}$ & $\begin{array}{c}33 / 71 \\
(46.5 \%)^{\star *}\end{array}$ & $\begin{array}{c}24 / 65 \\
(36.9 \%)^{\star *}\end{array}$ & $\begin{array}{c}2 / 41 \\
(4.9 \%)\end{array}$ & $\begin{array}{c}17 / 41 \\
(41.5 \%)^{\star *}\end{array}$ & $\begin{array}{c}16 / 46 \\
(34.8 \%)^{\star *}\end{array}$ \\
\hline Week 52 & - & $\begin{array}{c}38 / 71 \\
(53.5 \%)\end{array}$ & $\begin{array}{c}27 / 65 \\
(41.5 \%)\end{array}$ & - & $\begin{array}{c}19 / 41 \\
(46.3 \%)\end{array}$ & $\begin{array}{c}15 / 46 \\
(32.6 \%)\end{array}$ \\
\hline
\end{tabular}

${ }^{*} \mathrm{P}<0.05$ vs. $\mathrm{PBO},{ }^{* *} \mathrm{P}<0.001$ vs. $\mathrm{PBO}$, Fisher's exact test. Missing values imputed using nonresponder imputation.

${ }^{\text {aP }}$ atients with $\geq 0.35 \mathrm{HAQ}$-DI at baseline.

${ }^{\mathrm{b}} \mathrm{Good}$ response criteria defined as $>1.2$ improvement and $\leq 3.2$ present DAS28-CRP.

Conclusion: Both IXE Q4W and Q2W improved the signs and symptoms of PsA in a population of difficult-to-treat patients who have had inadequate response to 1 or 2 TNFi.

Disclosure of Interests: : L Bruce Kirkham Grant/research support from: Investigator for Janssen Research \& Development, LLC, Consultant for: Abbvie, Eli Lilly and Company, Janssen, Novartis, Carlos Sesin Grant/research support from: Eli Lilly and Company, Novartis, Roche, Consultant for: Eli Lilly and Company, Novartis, Pfizer, Amgen, Abbvie, Janssen, Speakers bureau: Eli Lilly and Company, Novartis, Pfizer, Celgene, Abbvie, Amgen, Radius, Regeneron/Sanofi Genzyme, Janssen, Aubrey Trevelin Sprabery Shareholder of: Eli Lilly and Company, Employee of: Eli Lilly and Company, Chen-Yen Lin Shareholder of: Eli Lilly and Company, Employee of: Eli Lilly and Company, Amanda M. Gellett Shareholder of: Eli Lilly and Company, Employee of: Eli Lilly and Company, Anthony Turkiewicz Grant/research support from: Janssen, Eli Lilly and Company, UCB, Pfizer, Regeneron Sanofi-Genzyme, Novartis, Consultant for: Janssen, Eli Lilly and Company, UCB, Pfizer, Regeneron Sanofi-Genzyme, Novartis, Abbvie, Medac, Horizon, Genentech

DOI: 10.1136/annrheumdis-2019-eular.1479

\section{OP0111 A RANDOMIZED, PHASE 3, DOUBLE-BLIND TRIAL EXAMINING METHOTREXATE AND ETANERCEPT AS MONOTHERAPY OR IN COMBINATION FOR TREATING PSORIATIC ARTHRITIS: A COMPARISON OF THE COMPOSITE MEASURES USED TO EVALUATE DISEASE ACTIVITY}

Philip J Mease ${ }^{1}$, Dafna D Gladman², David Collier ${ }^{3}$, Christopher T. Ritchlin ${ }^{4}$, Philip Helliwell $^{5}$, Laura C Coates ${ }^{6}$, Vibeke Strand ${ }^{7}$, Lyrica Liu ${ }^{3}$, Greg Kricorian ${ }^{3}$, James Chung ${ }^{3}$. 'Swedish Medical Center and University of Washington, Seattle, United States of America; ${ }^{2}$ University of Toronto, Toronto, Canada; ${ }^{3}$ Amgen Inc., Thousand Oaks, United States of America; ${ }^{4}$ University of Rochester Medical Center, Rochester, United States of America; ${ }^{5}$ University of Leeds, Leeds, United Kingdom; ${ }^{6}$ University of Oxford, Oxford, United Kingdom; ${ }^{7}$ Stanford University, Palo Alto, United States of America

Background: Optimal treatment regimens and measuring outcomes in psoriatic arthritis (PsA) remain key areas of research.

Objectives: To examine methotrexate (MTX) and etanercept (ETN) as monotherapy or in combination in a randomized trial and assess the relative performance of PsA-specific composite measures using trial efficacy data.
Methods: Patients with active PsA naïve to biologic drugs (no prior MTX for PsA) were randomized to 3 groups for 48 weeks: ETN 50mg+MTX 20mg weekly (Combo; $\mathrm{N}=283$ ); ETN 50mg+placebo weekly (ETN-mono; $\mathrm{N}=284$ ); or MTX $20 \mathrm{mg}+$ placebo weekly (MTX-mono; $\mathrm{N}=284$ ). At week 24, the American College of Rheumatology (ACR)20 and Minimal Disease Activity (MDA) responses were the primary and key secondary endpoints, respectively. Other PsA-specific composite measures used for disease activity included the Psoriatic Arthritis Disease Activity Score (PASDAS) and Disease Activity Index for Psoriatic Arthritis (DAPSA).

Results: Baseline characteristics were well balanced in the 3 arms. Mean (SD) age was 48.4 (13.1) years and mean/median PsA duration 3.2/0.6 years. ACR20 and MDA responses at week 24 were significantly greater with ETN-mono vs MTX-mono and Combo vs MTX-mono; ETN-mono and Combo had similar results (Table). PASDAS also showed differences between each ETN-containing arm vs MTX-mono and no difference for ETN-mono vs Combo, whereas study arm differences were not seen with DAPSA. PASDAS had a greater effect size and standardized response than DAPSA.

Conclusion: In this large randomized, controlled PsA trial, ETN-mono or Combo had greater efficacy than MTX-mono. Combining ETN and MTX did not improve ETN efficacy. Compared with the joint-focused DAPSA, PASDAS captured a wider range of PSA manifestations and performed better in this trial.

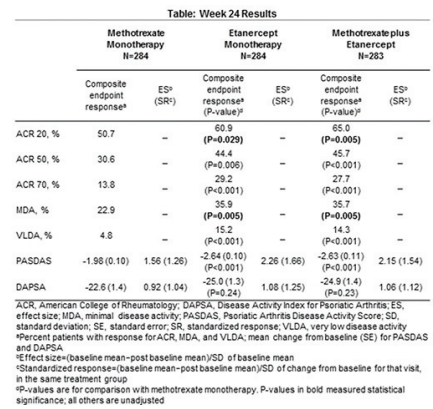

Disclosure of Interests: : Philip J Mease Grant/research support from: AbbVie, Amgen, BMS, Celgene, Janssen, Lilly, Novartis, Pfizer, SUN and UCB, Consultant for: AbbVie, Amgen, BMS, Galapagos, Gilead Sciences, Inc., Janssen, Lilly, Novartis, Pfizer, SUN and UCB, Speakers bureau: AbbVie, Amgen, BMS, Celgene, Genentech, Janssen, Lilly, Novartis, Pfizer and UCB, Dafna D Gladman Grant/research support from: AbbVie, Amgen, Celgene, Lilly, Novartis, Pfizer and UCB, Consultant for: AbbVie, Amgen, BMS, Celgene, Galapagos, Gilead, Janssen, Lilly, Novartis, Pfizer, and UCB, David Collier Shareholder of: Amgen Inc., Employee of: Amgen Inc., Christopher T. Ritchlin Grant/research support from: AbbVie, Amgen, UCB Pharma, Consultant for: AbbVie, Amgen, Lilly, Novartis, Pfizer, UCB Pharma, Philip Helliwell Grant/research support from: Paid to charity: from AbbVie, Janssen and Novartis, Consultant for: Paid to charity: from AbbVie, Amgen, Pfizer, and UCB and Celgene. Paid to self: from Celgene and Galapagos, Laura C Coates Grant/research support from: AbbVie, Celgene, Lilly, Novartis and Pfizer, Consultant for: AbbVie, Amgen, BMS, Celgene, Galapagos, Gilead Sciences Inc., Janssen, Lilly, Novartis, Pfizer, Prothena Corp and UCB Vibeke Strand Consultant for: AbbVie, Amgen, Bayer, BMS, Boehringer Ingelheim, Celgene, Celltrion, CORRONA, Crescendo, EMD Serono, Genentech/ Roche, GSK, Horizon, Inmedix, Janssen, Kezar, Lilly, Merck, Novartis, Pfizer, Regeneron, Samsung, Sandoz, Sanofi, Servier, UCB., Lyrica Liu Shareholder of: Amgen Inc., Employee of: Amgen Inc., Greg Kricorian Shareholder of: Amgen Inc., Employee of: Amgen Inc., James Chung Shareholder of: Amgen Inc., Employee of: Amgen Inc.

DOI: 10.1136/annrheumdis-2019-eular.783

\section{OP0112 UNACCEPTABLE PAIN DESPITE INFLAMMATION CONTROL AFTER START OF A FIRST ANTI-TNF THERAPY IN PATIENTS WITH PSORIATIC ARTHRITIS AND ITS RELATION TO TREATMENT RESPONSE}

Carmen Roseman ${ }^{1}$, Johan K Wallman ${ }^{1}$, Anna Jöud ${ }^{2}$, Maria Schelin ${ }^{3}$, Jon T Einarsson ${ }^{1}$, Elisabet Lindqvist ${ }^{1}$, Meliha C Kapetanovic ${ }^{1}$, Jon Lampa ${ }^{4}$, Tor Olofsson'. ${ }^{1}$ Lund University, Department of Clinical Sciences Lund, Rheumatology, Lund, Sweden; ${ }^{2}$ Lund University, Division of Occupational and Environmental Medicine, Lund, Sweden; ${ }^{3}$ Lund University, Department of Clinical Sciences Lund, Oncology, Lund, Sweden; ${ }^{4}$ Karolinska Institute, Department of Medicine, Rheumatology Unit, Stockholm, Sweden

Background: Pain is a major concern of patients with inflammatory arthritides, but while considerable focus has been put on the occurrence and 
management of pain due to inflammation, less is reported on pain despite inflammation control, with most such reports addressing rheumatoid arthritis (RA)

Objectives: To investigate the prevalence of pain despite inflammation control after start of a first anti-TNF therapy in psoriatic arthritis (PSA) patients and its relation to EULAR treatment response.

To test the feasibility of a network analysis approach to examine associations between clinical variables and mental health symptoms in RA.

Methods: PsA patients starting a first anti-TNF therapy 2004-2010 were identified in the prospective, observational South Swedish Arthritis Group register $(n=352$, $48 \%$ women), with mean age 47 years and mean disease duration 10 years. At anti-TNF start, $63 \%$ of patients had ongoing methotrexate and $68 \%$ were on any conventional DMARD(s). Based on the patient acceptable symptom state (PASS) 1 , unacceptable pain was defined as $>40 \mathrm{~mm}$ on a Visual Analogue Scale (VAS) of pain (scale 0-100 mm), and concomitant inflammation control (as in earlier RA studies) was captured through $\mathrm{CRP}<10 \mathrm{mg} / \mathrm{L}, 2$ in combination with $<1$ swollen joint (of 28).3 Assessments were performed at baseline, 1.5, 3, 6 and 12 months after anti-TNF start. Furthermore, analyses were conducted in relation to EULAR treatment response after 3 months (good, moderate, no response). Differences in pain measures between treatment response groups were estimated by logistic regression.

Results: At start of a first anti-TNF therapy, $84.5 \%$ of PsA patients reported unacceptable pain, which declined to $42.9 \%$ after 3 months and then remained stable during the rest of the study period, being $39.5 \%$ at 12 months (Figure $1 \mathrm{~A}$ ). In contrast, the fraction showing unacceptable pain despite inflammation control was largely unchanged over the study period $(24.0 \%$ at treatment start, $26.7 \%$ at 3 months and $26.2 \%$ at 12 months). Unacceptable pain at 3 months was strongly related to EULAR 3 -month response (23.7\% of good responders vs. $70.8 \%$ of non-responders; $p<0.001$ ), whereas for unacceptable pain despite inflammation control the relation was less pronounced (19.3\% of EULAR good responders vs $37.5 \%$ of non-responders, $p=0.016$ ). Among EULAR good responders, unacceptable pain despite inflammation control constituted $81 \%$ of all unacceptable pain at 3 months (Figure 1B).

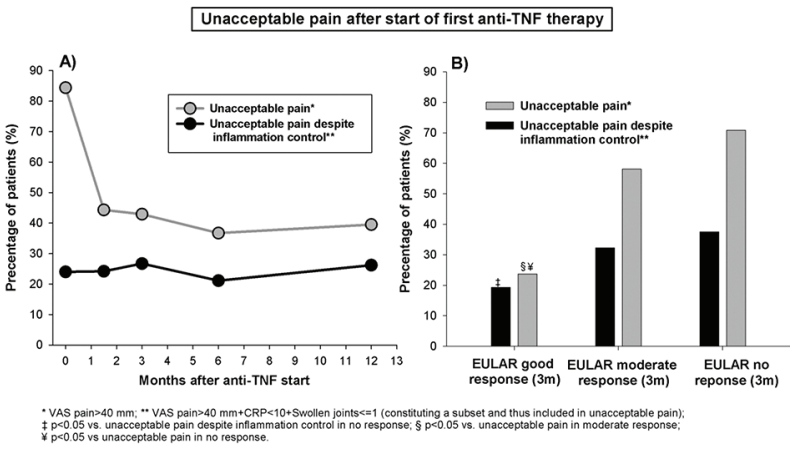

Conclusion: A considerable proportion of PsA patients starting their first biological treatment reported unacceptable pain throughout the first treatment year. Among EULAR good responders non-inflammatory pain made up more than $4 / 5$ of this pain load at 3 months, indicating insufficient effects of biologics on a subset of patients with inflammation-independent pain, and strongly warrants alternative treatment strategies in affected patients.

\section{REFERENCES:}

[1] Tubach et al. Arthritis Care Res 2012;64:1699-72.

[2] Lourdudoss et al. Arthritis Care Res. 2018;70:205-12.

[3] Olofsson et al. Ann Rheum Dis 2018;77:S2.

Acknowledgement: Associate professor Pierre Geborek

Disclosure of Interests: Carmen Roseman: None declared, Johan K Wallman Consultant for: Consultant for AbbVie, Celgene, Eli Lilly, Novartis, and UCB Pharma., Anna Jöud: None declared, Maria Schelin: None declared, Jon T Einarsson: None declared, Elisabet Lindqvist: None declared, Meliha C Kapetanovic: None declared, Jon Lampa Grant/ research support from: Abbvie, Consultant for: Eli Lilly, Sandoz, Tor Olofsson: None declared

DOI: 10.1136/annrheumdis-2019-eular.1839

\section{OP0113 \\ HISTOLOGICAL AND MOLECULAR PORTRAIT OF THE SYNOVIAL TISSUE IN EARLY TREATMENT-NAÏVE PSORIATIC ARTHRITIS IN COMPARISON WITH RHEUMATOID ARTHRITIS}

Alessandra Nerviani ${ }^{1}$, Gloria Lliso Ribera ${ }^{1}$, Marie Astrid Boutet ${ }^{1}$, Katriona Goldmann ${ }^{1}$, Stephen Kelly ${ }^{2}$, Michele Bombardieri ${ }^{1}$, Myles Lewis ${ }^{1}$, Frances Humby ${ }^{1}$, Costantino Pitzalis ${ }^{1}$. 'William Harvey Research Institute, Queen Mary University of London, UK, Centre for Experimental Medicine and

Rheumatology, London, United Kingdom; ${ }^{2}$ Barts Health NHS Trust, Rheumatology, London, United Kingdom

Background: Psoriatic Arthritis (PsA) and Rheumatoid Arthritis (RA) are autoimmune joint diseases characterised by chronic inflammation of the synovial tissue (ST). It has been previously suggested that PSA-ST has less marked hyperplasia of the synovial lining and fewer infiltrating T/B cells in comparison with RA. However, several confounders such as treatment, disease duration, sampling techniques and predominance of large joints samples may have influenced these findings.

Objectives: To compare the synovial features of PsA/RA at the beginning of the disease process and prior to any treatment for defining their histological/molecular individual characteristics, and to correlate the histological pattern with clinical parameters.

Methods: 183 consecutive treatment-naïve patients with $<12$ months symptoms and active synovitis of at least one joint were enrolled into the Pathobiology of Early Arthritis Cohort (PEAC) at the Barts Health NHS Trust, and underwent a baseline US-guided synovial biopsy of an inflamed joint. ST inflammatory infiltrate was evaluated by semi-quantitative score (0-4) of the immunostaining for CD68 (macrophages), CD3 (T cells), CD20 (B cells) and CD138 (plasma cells). Patients were classified as: pauci-immune if CD68sublining $(\mathrm{SL})<2$ and/or CD3-CD20 CD138<1; diffuse-myeloid if CD68SL $\geq 2, C D 20<2$ or CD138<2; lymphoid-myeloid if $C D 20 \geq 2$ or $C D 138>2$. RNA sequencing of the ST was performed on 93RA 15PsA patients.

Results: $39 / 183$ patients were diagnosed with PsA (32 polyarticular, 7 oligoartic ular) and 144/183 with RA (2010 ACR/EULAR criteria). Age was significantly lower in PsA patients. The comparison of the age-adjusted baseline variables showed: significantly higher number of tender and swollen joints in RA, but no significant differences between ESR, CRP and DAS28; higher US synovial thickening score of the biopsied joint in PsA, but comparable power-doppler. ST was obtained from small joints in $74.4 \%$ of PsA and $82 \%$ of RA. Histological comparison is summarised in Table 1 and 2. Only in RA, the pauci-immune pathotype associated with significantly lower ESR, CRP and DAS28 compared to lymphoidmyeloid; this association was maintained in a subset of 26 RA patients age- and gender-matched with the PSA population. Transcriptomic profiling showed that PSA-ST has significantly higher expression of the skin fibroblasts, eosinophils and neutrophils cellular gene modules. Genes significantly up regulated in PsA clustered in neutrophil recruitment/enrichment, cell migration and cytoskeleton remodelling modules.

\begin{tabular}{|c|c|c|c|}
\hline & $\begin{array}{c}\text { PsA } \\
(n=37)\end{array}$ & $\begin{array}{c}\text { RA } \\
(n=125)\end{array}$ & $p$ value \\
\hline CD3 & $0.9(1)$ & $1.7(1.3)$ & $0.0045^{\star}$ \\
\hline CD20 & $\begin{array}{c}0.8 \\
(1.1)\end{array}$ & $1.4(1.5)$ & $0.03^{\star}$ \\
\hline CD68L & $\begin{array}{c}1.5 \\
(1.3)\end{array}$ & $1.8(1.2)$ & 0.16 \\
\hline CD68SL & $\begin{array}{c}1.8 \\
(1.2)\end{array}$ & $2.3(1.2)$ & $0.04^{\star}$ \\
\hline \multirow[t]{2}{*}{ CD138 } & $\begin{array}{c}0.8 \\
(1.2) \\
\end{array}$ & $1.4(1.5)$ & $0.02^{*}$ \\
\hline & $\begin{array}{c}\text { PsA } \\
(n=37)\end{array}$ & $\begin{array}{c}\text { RA } \\
(n=125)\end{array}$ & $p$ value \\
\hline Pauci-immune & $16(43.2 \%)$ & 31 (24.8\%) & 0.056 \\
\hline Diffuse-Myeloid & $12(32.4 \%)$ & $40(32 \%)$ & \\
\hline Lymphoid-Myeloid & $9(24.4 \%)$ & $54(43.2 \%)$ & \\
\hline
\end{tabular}

Conclusion: The identification of specific histological and molecular signatures characterising early-untreated PSA will help to better understand the disease pathogenesis and explore novel therapeutic targets.

\section{REFERENCE:}

[1] van Kuijk AW, Tak PP. Synovitis in psoriatic arthritis: immunohistochemistry, comparisons with rheumatoid arthritis, and effects of therapy. Curr Rheumatol Rep. 2011 Aug;13(4):353-9

Disclosure of Interests: Alessandra Nerviani: None declared, Gloria Lliso Ribera: None declared, Marie Astrid Boutet: None declared, Katriona Goldmann None declared, Stephen Kelly: None declared, Michele Bombardieri Grant/ research support from: Celgene, Consultant for: Medimmune, Myles Lewis Grant/ 